\title{
North Central States
}

National Cancer Institute

\section{Source}

National Cancer Institute. North Central States. NCI Thesaurus. Code C43449.

The area in the United States comprised of the following states: Michigan, Ohio, Indiana, Kentucky. 